\title{
Competition Indexes to Evaluate Tree Growth in a Semi-Deciduous Seasonal Forest
}

\author{
Ilvan Medeiros Lustosa Junior ${ }^{1,2}$ (D), Renato Vinícius Oliveira Castro ${ }^{2,3}$ (D), \\ Ricardo de Oliveira Gaspar ${ }^{2}$ (D), Juliana Baldan Costa Neves Araújo² (1), \\ Fabiana de Gois Aquino ${ }^{4}$ \\ ${ }^{1}$ Instituto Federal de Brasília (IFB), Planaltina, DF, Brasil \\ ${ }^{2}$ Universidade de Brasília (UnB), Brasília, DF, Brasil \\ ${ }^{3}$ Universidade Federal de São João del Rei (UFSJ), Sete Lagoas, MG, Brasil \\ ${ }^{4}$ Empresa Brasileira de Pesquisa Agropecuária dos Cerrados (Embrapa), Brasília, DF, Brasil
}

\begin{abstract}
Most of the studies that analyze the behavior of tree competition approach even-aged plantations. Therefore, it is possible to notice a lack of this kind of information regarding natural forests with high biodiversity. The objective of this study was to evaluate the competition in a fragment of Semi-Deciduous Seasonal Forest, according to the ecologic group, light depending and nondepending groups for all species sampled in the fragment. The Distance Independent Competition Index and Semi-Distance Independent Competition Index were applied in this study. The basal area in larger trees index, without the radius of influence, was the most efficient to analyze how the competition affects the growth of the specimens in the studied fragment. It was stated that evaluating the competition per ecologic group is more efficient. The results confirm that the forest competition cannot be determined by considering only a fixed radius of influence that embraces the neighbors and the subject tree.
\end{abstract}

Keywords: Atlantic Forest, ecologic groups, radius competition, forest management.

\section{Índices de Competição na Avaliação do Crescimento Arbóreo em Floresta Estacional Semidecidual}

\section{RESUMO}

A maioria dos estudos que analisa o comportamento da competição arbórea é voltada para plantios homogêneos e equiâneos. Nota-se, portanto, uma carência de informações deste tipo em florestas naturais de elevada biodiversidade. Objetivou-se com este trabalho avaliar a competição em um fragmento de Floresta Estacional Semidecidual, por grupo ecológico, grupos demandantes e não demandantes de luz para todas as espécies amostradas no fragmento. Foram empregados índices de competição independentes da distância e semidependentes da distância. O índice BAL (basal area in larger trees), sem raio de influência, obteve o melhor desempenho para analisar como a competição afeta o crescimento dos indivíduos no fragmento estudado. Concluiu-se que avaliar a competição por grupo ecológico é mais eficaz, e os resultados confirmam que a competição florestal não pode ser determinada apenas pela aplicação de um raio fixo de influência dos vizinhos em relação à árvore-objeto.

Palavras-chave: Mata Atlântica, grupos ecológicos, raios de concorrência, manejo florestal. 


\section{INTRODUCTION AND OBJECTIVES}

Forest competition consists in a direct relation between increase of demand for resources which are necessary for the plants' growth and decrease of its availability. Depletion or even scarcity of those resources results in some profound implications for ecology and forest handling. Therefore, it is believed that the competition process among trees retracts diameter's growth and increases mortality rate (Lee, 1971).

One of the techniques utilized to evaluate forest competition consists of applying competition indexes. According to Boivin (2010), a variety of them, spatial or not, were developed to estimate competition's effect on individual trees' growth or within a tree stand. To Castro (2014), efficiency in growth's modeling on an individual's tree level can be greater with the usage of competition indexes.

Competition indexes conceptually differ due to criteria utilized to express relations among trees. On published works, the following are known and considered: distance dependent indexes (IDD), independent on distance (IID) and semi-dependent on distance (ISD) (Contreras et al., 2011; Stage \& Ledermann, 2008). Within those distance dependent indexes, spatial coordinates are attributed to each tree, which allow one to ponder competition among each tree and its neighbors, resulting in more complex and precise ways of gathering data (Hynynen, 1995).

Distance independent indexes do not utilize information regarding spatial distribution of individuals, being quantified by ratio between trees' diameter and/or height, and also tree stand variables, such as basal area, average diameter and average height (Castro, 2014).

According to Contreras et al. (2011), ISD calculation is applied independently of distance, but restrains the set of neighbor trees based upon locations of parts of ISD inventory. An aspect inherent to ISD application is that competition is analyzed within a specific set of trees, according to a determined influence radius.

Most of the studies that analyze tree's competition behavior is set towards homogeneous and even-aged plantations. One may notice a lack of this kind of information regarding natural forests containing high biodiversity. One of the biggest challenges refers to the difficulty regarding gathering data, due to inherent environmental obstacles, such as terrain, hard to reach locations, high density of individuals, and species diversity found within the natural forest.

Few are the studies that evaluate trees' competition effects utilizing attributes such as distance between species or groups of tree species in tropical forests (Chassot et al., 2011; Cunha \& Finger, 2013; Orellana et al., 2016). Therefore, the objective of this work was to evaluate efficiency on applying competition indexes in a fragment of a Semi-Deciduous Seasonal Forest in the state of Minas Gerais, Brazil, following classification by ecological group, tolerant and intolerant to shadow groups, and for all species in general.

\section{MATERIALS AND METHODS}

The study was conducted in the city of Caratinga, MG, located in the geographical coordinates $19^{\circ} 47^{\prime} 25^{\prime \prime}$ ' 42 08'21"W, related to Lagoa do Piau Project, which has an area of 256,94 ha. It consists in a fragment of the Atlantic Forest, characterized as Semi-Deciduous Seasonal Forest (IBGE, 2012). According to Köppen's classification (1923), its climate is in the "Aw" category, with temperatures varying between $19,1^{\circ} \mathrm{C}$ and $28,3{ }^{\circ} \mathrm{C}$, and average annual precipitation equivalent of $1,373 \mathrm{~mm}$. Twentytwo permanent plots measuring $10 \times 50 \mathrm{~m}$, that is, $500 \mathrm{~m}^{2}$, were installed. The total height $(\mathrm{Ht})$ and the diameter at breast height (DBH) of $1.30 \mathrm{~m}$ of trees with DBH greater than or equal to $5 \mathrm{~cm}$ were identified and measured in each plot in 2002, 2007 and 2012 (Table 1).

The collected botanical material was identified by specialists through comparisons with materials from the Department of Vegetal Biology from Universidade Federal de Viçosa (UFV). The utilized classification system was APG III (2009).

For each tree, $\mathrm{x}$ and $\mathrm{y}$ coordinates were determined in relation to its plot's origin and a location map of individuals was created with the help of software ArcGis 10. For calculating the distances between each tree and its competitors, the tool Point Distance, available in the aforementioned software, was used.

Independent of distance competition (IID) and semi-dependent of distance (ISD) indexes were applied for each bole, in each measuring (Table 2). 
Table 1. Description of data collected in a mountain semi-deciduous seasonal forest fragment, in Caratinga, MG, Brazil.

\begin{tabular}{cccc} 
& \multicolumn{3}{c}{ Year of measurement } \\
\cline { 2 - 4 } & 2002 & 2007 & 2012 \\
\hline Minimum DBH $(\mathrm{cm})$ & 4.8 & 4.8 & 5.0 \\
\hline Average DBH $(\mathrm{cm})$ & 9.5 & 9.8 & 10.3 \\
Maximum DBH $(\mathrm{cm})$ & 65.6 & 69.4 & 75.1 \\
\hline q $(\mathrm{cm})$ & 11.0 & 11.3 & 11.8 \\
\hline Minimum Ht $(\mathrm{m})$ & 1.7 & 1.3 & 2.5 \\
\hline Average Ht $(\mathrm{m})$ & 8.8 & 9.0 & 10.3 \\
\hline Maximum Ht $(\mathrm{m})$ & 30.0 & 30.0 & 30.0 \\
\hline Basal Area $\left(\mathrm{m}^{2}\right.$ ha $\left.{ }^{-1}\right)$ & 19.9 & 21.3 & 21.9 \\
\hline Botanical families & 51 & 51 & 46 \\
\hline Botanical genres & 100 & 101 & 95 \\
\hline Identified species & 129 & 120 & 123 \\
\hline Non-identified species & 4 & 5 & 8 \\
\hline Number of boles (ha) & 2105 & 2122 & 1996 \\
\hline
\end{tabular}

DBH: diameter of bark hull of $1.30 \mathrm{~m}$; q: quadratic diameter; Ht: total height; number of boles (ha): number of trunks, counting every ramification below DBH.

Table 2. Distance independent competition indexes applied in this research.

$$
I I D 1=\frac{d a p_{i}^{2}}{d^{2}} \quad \text { Glover \& Hool (1979) }
$$

$$
\text { IID2 }=\frac{H t_{i}}{H t} \quad \text { Glover \& Hool (1979) }
$$

$$
\text { IID3 }=\frac{d a p_{i}^{2} \cdot H t_{i}}{\bar{d}^{2} \cdot \overline{H t}} \quad \text { Glover \& Hool (1979) }
$$

$$
\begin{array}{rlr}
I I D 4 & =\frac{A S_{i}^{2}}{A S q^{2}} & \text { Stage (1973) } \\
I I D 5 & =B A L_{i} & \text { Stage (1973) }
\end{array}
$$

$D B H$ i: diameter with subject-tree's bark hull's bole, measured at $1,30 \mathrm{~m}(\mathrm{~cm}) ; d$ : arithmetical average of boles' diameters from sample unit of 0,5 ha; Hti: total height of tree bole (m); Ht: average bole height of sample unit (m); ASi: sectional area of subject tree bole, measured at $1,30 \mathrm{~m}$ tall $\left(\mathrm{m}^{2}\right)$; $A S q$ : sectional area correspondent to average sectional diameter $(q)$ of neighbor trees boles $\left(\mathrm{m}^{2}\right) ; B A L i$ : sum of sectional neighbor trees boles larger than subject trees boles.

For calculating the semi-dependent distance indexes, the independent indexes were limited to a range of influence (Figure 1). Containing radius between 2 and 6 meters circumference, within 1 meter intervals, the dendrometric variables and its radius of influence were taken into consideration.

Some authors have defined which trees, neighbors to the subject tree, are effectively competitors, considering a fixed radius around the subject tree (Contreras et al., 2011; Das, 2012; Orellana et al., 2016). A 6-meters radius was chosen as the limit to evaluate competition influence (Table 3). It is believed that the closer they are from the borders of the plot, the more incomplete or less precise the competition index becomes, so the influence of trees outside the plot limits was not taken into consideration. 




2-meters radius of influence $\quad 3$-meters radius of influence $\quad 4$-meters radius of influence

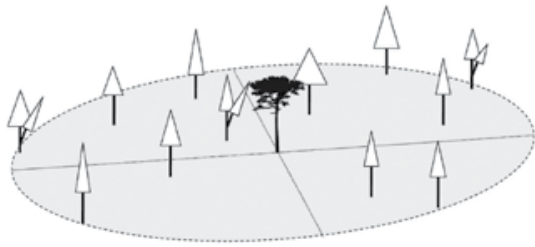

5-meters radius of influence



6-meters radius of influence

Figure 1. Outline of the radius of influence delimitation in 2, 3, 4, 5, and 6 meters, used to calculate the distance semi-independent indexes.

Table 3. Description of the distance independent and semi-distance dependent competition indexes.

\begin{tabular}{ccccccc} 
Competition index & $\begin{array}{c}\text { Radius of } \\
\text { influence }\end{array}$ & \multicolumn{3}{c}{ Notation } & & \\
\hline $\begin{array}{c}\text { Distance independent } \\
\text { indexes }\end{array}$ & ------- & IID1 & IID2 & IID3 & IID4 & IID5 \\
\hline & 2 meters & ISD1/2 & ISD2/2 & ISD3/2 & ISD4/2 & ISD5/2 \\
\cline { 2 - 5 } Semi-distance dependent \\
indexes & 3 meters & ISD1/3 & ISD2/3 & ISD3/3 & ISD4/3 & ISD5/3 \\
& 4 meters & ISD1/4 & ISD2/4 & ISD3/4 & ISD4/4 & ISD5/4 \\
& 5 meters & ISD1/5 & ISD2/5 & ISD3/5 & ISD4/5 & ISD5/5 \\
& 6 meters & ISD1/6 & ISD2/6 & ISD3/6 & ISD4/6 & ISD5/6 \\
\hline
\end{tabular}

An explanation for the indexes' behavior relates to the influence of the competing trees outside the plots enveloping the object trees (Orellana et al., 2016). Therefore, the assessment becomes incoherent, since it would not be possible to analyze the influence of the competition of trees located outside the radius and to what extent the influence is exerted on the individual trees within the radius.

After calculation of competition indexes, a graphical analysis was made relating annual growth in diameter and height with each applied index. To the level of $95 \%$ of probability, a linear correlation matrix was elaborated between indexes and annual growth in diameter $(\triangle \mathrm{DBH})$ and annual growth in height $(\Delta \mathrm{Ht})$, gathered between each measuring interval.

The species present inside the forest fragment were classified, according to Gaspar et al. (2014), in the following ecological groups: pioneers, early secondaries, late secondaries, and climax. After this classification, successional groups were organized into two main segments, using as criteria how necessary light was, between light demanding and shade tolerant plants. In this sense, correlations between competition levels, diameter, and height growth of individuals were also verified per group. 


\section{RESULTS AND DISCUSSION}

The biggest standard deviation found to the DBH variable was from the successional climax group, while for the Ht variable, groups of all species presented a greater dispersion of values in relation to the average (Table 4). When analyzing the relation between standard deviation and correlations found amongst competition indexes and those variables in question, one may find that lower and non-significant correlations belonged to those groups, which presented a greater variation amongst data in relation to the average. This behavior can be found on $\mathrm{Ht}$ variable of the climax group, which mostly consisted in nonsignificant correlations.

Average diameter and height growths presented a similar tendency when correlated to all competition indexes, independent and semi-dependent (Figure 2). Competition indexes behavior is influenced by dendrometric variables aggregated in each index, in which each one responded according to the dendrometric variable present in its equation.

When Castro (2014) evaluated, specifically for the applied indexes, competition within the fragment of Semi-Deciduous Seasonal Forest in the city of Viçosa, MG, he found that this behavior indicates that boles which presented their dendrometric variable inferior to the average of neighbor boles presented lower indexes, resulting in lower growth.

However, it is necessary to remember that the fact that the index itself is greater or lower according to individual competition follows mathematical principles. Therefore, values depend on functional index formula, since that if variables are directly or inversely proportional to competition, or if the index is the sum of basal areas from neighbor-trees, it is expected that the greater the index, the greater the competition. On the other hand, if the index formula is 1 divided by the sum of basal neighbor trees' area, this relation is inverted.

According to Chassot (2011), Glover and Hool indexes express the idea that the greater the values, the smaller the competition to which the tree is submitted, thus presenting higher levels of growth.

The basal area in larger trees (BAL) competition index is presented in a different way than others. Since this index expresses competition pertinent to all neighboring individuals taller than the subject tree, it is expected, therefore, that the lesser the values of those indexes, the larger the tree's diameter, and as a consequence, the smaller the competition to which the subject tree is submitted. From that, one can explain the fact that most of the found correlation to this index is negative. Therefore, this behavior can be associated to biological realism inherent to the competition index.

Those correlations that presented meaningfulness, in their majority, were derived from interactions between competition indexes and growth in diameter. As for the height growth, when it is verified competition among all species of fragment, with no possibility of grouping, one may notice correlations presented less meaningful values, in relation to the competition indexes applied in this study (Table 5).

According to Castro (2014), gathering of low correlations can be explained due to high level of forest composition, since it has a high heterogeneity regarding species, ages of trees, general growth, and sanity conditions, among others. Even with low values, simple correlation with growth in diameter and height

Table 4. Ratio between average DBH and average $\mathrm{Ht}$ and their respective standard deviations.

\begin{tabular}{ccc} 
Group & DBH \pm Standard deviation & Ht \pm Standard deviation \\
\hline All & $11.3 \pm 3.2$ & $10.8 \pm 2.7$ \\
\hline Pioneers & $10.9 \pm 3.7$ & $9.8 \pm 2.9$ \\
Early secondaries & $9.7 \pm 3.0$ & $10.3 \pm 2.9$ \\
Late secondaries & $9.9 \pm 3.1$ & $9.3 \pm 2.8$ \\
\hline Climax & $11.4 \pm 4.3$ & $9.6 \pm 2.9$ \\
Light demanding & $9.8 \pm 3.1$ & $9.7 \pm 2.9$ \\
Shade tolerant & $11.4 \pm 4.0$ & $9.9 \pm 2.9$ \\
\hline
\end{tabular}

DBH: diameter at breast height; Ht: total height. 
has been a common criterion to selection of competition indexes (Weber et al., 2008).

Martins et al. (2011), while considering forest growth behavior, have noticed a rise in index correlation values, based on the fact that in equidistant forests, same-sized trees present similar growth levels. Even regarding native forests, such tendency was also verified in the present study, in which is important to mention that forest fragment characterized a dynamic totally different from the aforementioned research, since within equidistant forests variables, there are some under control that influence its growth, such as favorable conditions of nutrition and soil fertility, humidity, silvicultural treatment, among others.

Figure 2. Independent competition indexes and semi-distance dependent due to the regular periodic annual growth in diameter and height.
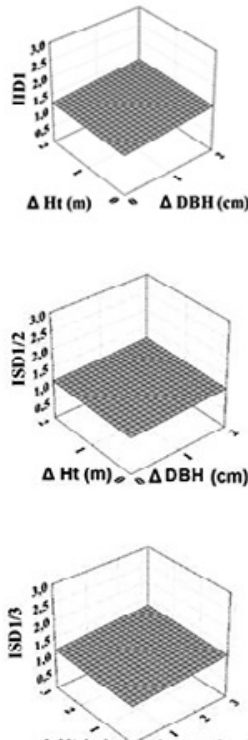

$\Delta H t(m) \circ \Delta \overline{D B H}(\mathrm{~cm})$
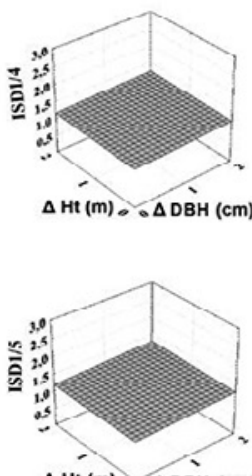

$\Delta \mathrm{Ht}(\mathrm{m}) \odot \triangle \triangle \mathrm{DBH}(\mathrm{cm})$

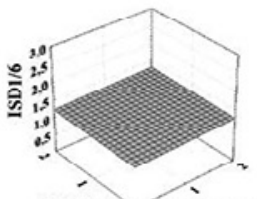

$\Delta H t(m) \odot \triangle D B H(c m)$
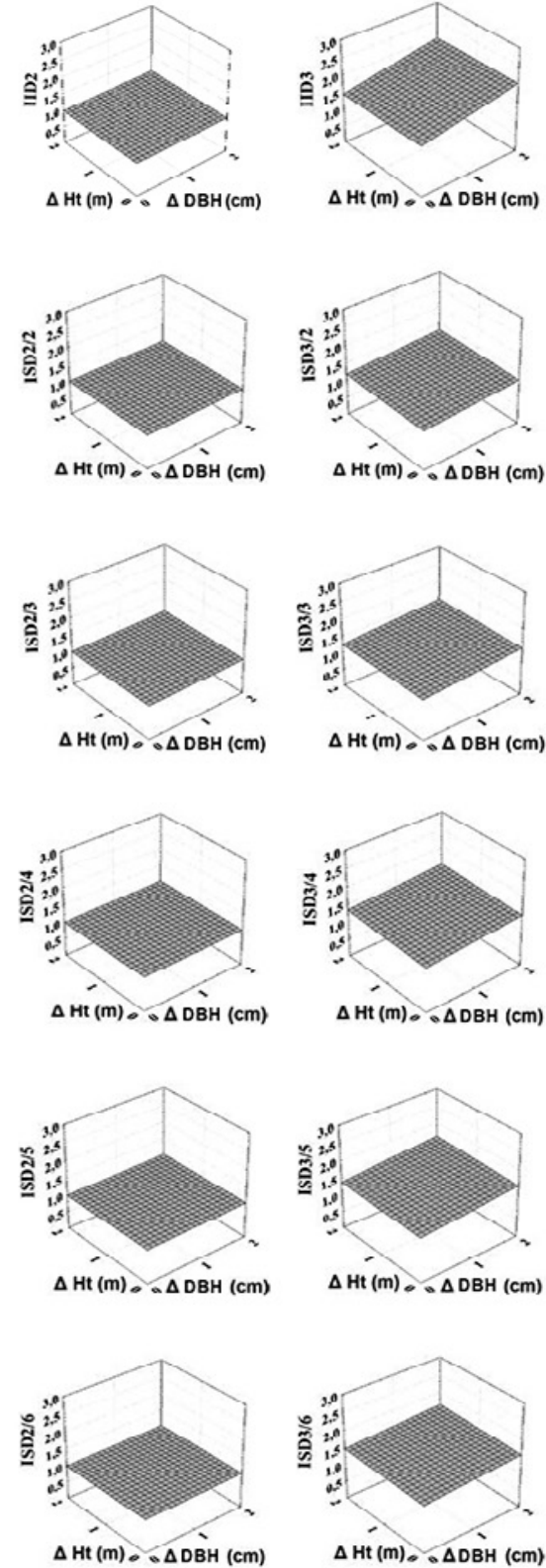
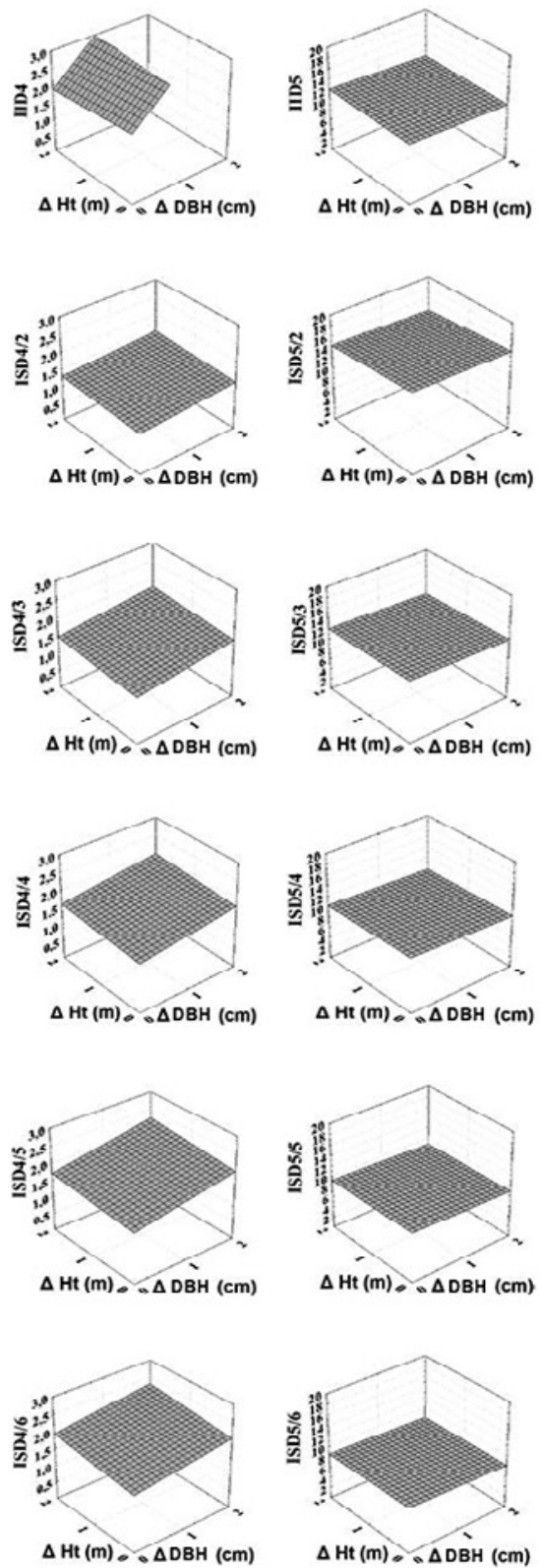
Table 5. Linear correlations of distance independent and semi-distance independent of competition indexes for all specimens disregarding classification per group.

\begin{tabular}{|c|c|c|}
\hline \multirow{2}{*}{ Index } & $\triangle \mathrm{DBH}$ & $\Delta \mathbf{H t}$ \\
\hline & \multicolumn{2}{|c|}{------------- $\%$------------- } \\
\hline IID1 & $5.53^{\star}$ & $1.07^{\text {n.s }}$ \\
\hline IID2 & $8.27^{*}$ & $-0.71^{\mathrm{n} . \mathrm{s}}$ \\
\hline IID3 & $7.32^{\star}$ & $-0.46^{\mathrm{n} . \mathrm{s}}$ \\
\hline IID4 & $7.85^{*}$ & $-0.60^{\text {n.s }}$ \\
\hline IID5 & $-9.69^{*}$ & $3.63^{*}$ \\
\hline ISD1/ 2 & $7.31^{\star}$ & $4.30^{*}$ \\
\hline ISD2/ 2 & $8.42^{*}$ & $1.21^{\mathrm{n} . \mathrm{s}}$ \\
\hline ISD3/ 2 & $7.82^{\star}$ & $3.34^{\mathrm{n} . \mathrm{s}}$ \\
\hline ISD4/ 2 & $7.92^{\star}$ & $5.02^{\star}$ \\
\hline ISD5/ 2 & $-1.47^{\mathrm{n} . \mathrm{s}}$ & $-2.60^{\text {n.s }}$ \\
\hline ISD1/ 3 & $7.34^{*}$ & $3.41^{\mathrm{n} . \mathrm{s}}$ \\
\hline ISD2/ 3 & $8.45^{\star}$ & $-0.20^{\mathrm{n} . \mathrm{s}}$ \\
\hline ISD3/ 3 & $8.35^{\star}$ & $2.72^{\mathrm{n} . \mathrm{s}}$ \\
\hline ISD4/ 3 & $8.06^{*}$ & $4.41^{\star}$ \\
\hline ISD5/ 3 & $-2.26^{\mathrm{n} . \mathrm{s}}$ & $-0.54^{\mathrm{n} . \mathrm{s}}$ \\
\hline ISD1/ 4 & $4.41^{\star}$ & $3.76^{*}$ \\
\hline ISD2/ 4 & $8.47^{\star}$ & $0.97^{\text {n.s }}$ \\
\hline ISD3/ 4 & $5.77^{\star}$ & $2.75^{\text {n.s }}$ \\
\hline ISD4/ 4 & $6.85^{\star}$ & $3.89^{*}$ \\
\hline ISD5/ 4 & $-3.60^{*}$ & $-1.87^{n . s}$ \\
\hline ISD1/ 5 & $5.32^{\star}$ & $3.72^{\star}$ \\
\hline ISD2/ 5 & $8.16^{*}$ & $0.91^{\mathrm{n} . \mathrm{s}}$ \\
\hline ISD3 /5 & $6.37^{\star}$ & $2.50^{\mathrm{n} . \mathrm{s}}$ \\
\hline ISD4/ 5 & $7.52^{\star}$ & $3.59^{\text {n.s }}$ \\
\hline ISD5/ 5 & $-4.86^{\star}$ & $-1.65^{\text {n.s }}$ \\
\hline ISD1/ 6 & $3.33^{\text {n.s }}$ & $3.68^{*}$ \\
\hline ISD2/ 6 & $8.05^{\star}$ & $0.41^{\text {n.s }}$ \\
\hline ISD3/ 6 & $4.04^{*}$ & $2.31^{\mathrm{n} . \mathrm{s}}$ \\
\hline ISD4/ 6 & $4.37^{\star}$ & $3.59^{\star}$ \\
\hline ISD5/ 6 & $-5.42^{*}$ & $-1.17^{\mathrm{n} . \mathrm{s}}$ \\
\hline
\end{tabular}

*: indicates meaningful correlations; $n$.s.: indicates non-meaningful correlation, by $95 \%$ of probability; $\triangle \mathrm{DBH}$ : growth in diameter; $\Delta \mathrm{Ht}$ : growth in height.

Among the independent and semi-distance dependent indexes, the ones containing radius of 4 and 5 meters of influence stood out when compared to the remaining ones. It has been seen that correlations seemed to be superior and more meaningful to growth in diameter, which made it possible to characterize competition to all individuals within the fragment.
While verifying correlations between levels of competition and growth in height, one may notice predominance of non-meaningful values. Taking this analysis into consideration, it is therefore assumed that, for this fragment and under similar characteristics, growth in height is not recommended when one intends to study forest competition by means of competition indexes. Still regarding variable height, it was observed that other indexes containing height in their functional formula do not present good results.

Forest competition within the fragment in question is notorious for the meaningfulness of the majority of the obtained correlations. When observing the correlations between applied indexes and growth in diameter, one may notice that the distance independent BAL has presented greater correlation in module, among others.

All indexes, distance dependent or independent, which consist in the sum of sectional areas of trees bigger than subject trees, have presented negative correlations for diameter growth, with the exception of indexes ISD5/2 and ISD5/3, which were not meaningful in the evaluation of forest competition. It implies then that semi-distance dependent indexes, with radius of 2 and 3 meters, do not offer a satisfactory explanation to competition among individuals for the analyzed measuring interval.

Chassot et al. (2011), while verifying competition among individuals of Araucaria angustifólia (Bertol.), have recorded that diameter has presented a negative correlation with BAL competition indexes.

Considering the fact that forest formations are completely different in their compositions, it is possible to deduce that the smaller the competition to which they are submitted, the smaller the growth of subject trees. One of the explanations for obtaining these results is the relation between diameter dimension of main tree and competition. The smaller the BAL index, the lower the competition to which the tree is submitted, allowing it to grow more. It results in greater diameter achieved by the subject tree.

Martins et al. (2011) have analyzed competition among individuals of Eucalyptus sp. and have found similar results to the ones within this work, mainly when considering correlations between growth in diameter by BAL indexes. It is worth noticing that this comparison is made under totally different conditions of vegetation than the object of study of the current work. 
According to Eid \& Tuhus (2001), BAL index is an excellent competition index, for it does not need spatial information of each BAL tree. However, in this study, this index was applied to different radius of influence.

It is derived therefore that the behavior of $\mathrm{BAL}$ index is related to the level of complexity inherent to the type of vegetation analyzed, as well as variables that can influence in the increase of basal area of individuals. The advantage in evaluating competition by BAL index, according to Martins et al. (2011), is its less complex form and its biological realism, since this index utilizes basal area as an independent variable, by which itself already shows the competitive status of each tree, with no necessity to incorporate further variables within the model.

Cunha (2009) has evaluated the competition of other trees of the species Cedrela odorata L. and has concluded that BAL index was not satisfactory to explain variation in growth, possibly due to the fact that thicker trees do not present sufficient competition in order to interfere upon the species' growth.

When individuals are classified in successional groups (pioneers, early secondaries, late secondaries, and climax) some clear differences within values of correlations are noted (Table 6). Group of pioneers has presented only BAL indexes: distance independent and the ones with 5 and 6 meters of radius, just as the three indexes that obtained meaningful correlations among the four, when correlated to diameter growth. Such behavior can be justified under the perspective that this group is highly dependent on light for its growth, then is more prone to competition. On the other hand, all indexes of this group have presented non-meaningful correlations when growth in height was considered.

In heterogeneous and all-aged native tree stands, the many different species present distinct genetical characteristics, adapted to specific ecological niches (Vaccaro et al., 2003). Therefore, in natural forests, growth behavior can generate different answers according to greater or lesser distance to preferred habitat and its position within forest structure.

One may observe that in almost all indexes correlations rise as in successional stage changes from pioneer to climax (Table 6). It is noted that correlations to same index within the group of climax are always greater than pioneers. This suggests that the growth of trees in later stages of ecological succession has a more regular pattern, considering that it does not depend that much on forest light conditions.

Since forest component tends to stabilize in terms of growth reaching its climax state, Carvalho (1997) has reported that not only there is variation of growth among species, there may also be variation within the same species, considering there is difference in size and crowns' lighting, along with genetical factors. According to these characteristics, Silva et al. (1995) have observed that differences in growth regarding ecologic groups of species are important, and so must be considered when it comes to modeling forest growth.

Most correlations relevant to diametrical growth in relation to applying competition indexes was meaningful in the group of early secondaries. By analyzing influence of tree competition within a radius of 2 meters, ISD4 being applied, it has been observed superiority of this index to this ecological group, which presented the greatest meaningful correlation.

For the growth in height, the index which presented the highest correlation was also ISD4, with radius of 2 meters. Researchers, such as Biging \& Dobbertin (1995), claim that applying the 6-meter radius of competition shows superior results when compared to other radiuses, which is in accordance to studies of Béland et al. (2003), who have also obtained better results with this radius of competition in another forest formation. However, in the study in question, 2-meters radius has seemed to be sufficient to analyze competition when species are organized in ecologic groups.

The late secondaries group showed a better ISD2 semi-distance dependent index with radius of 6 meters, containing $16.75 \%$ of correlation with diametrical incrementation. When verifying the correlations with growth in height, it was observed that none of the indexes has shown meaningful correlation, which allows one to deduce that the relation between growth in height and indexes is not indicated to analyze competition among species of this group to a time interval equal to the one applied in the study in question (Table 6).

Considering diametrical growth, IID3 has presented the greatest meaningful correlation $(31.21 \%)$ among all successional groups evaluated. It is valid to emphasize that such index derives from ratio produced by combination of dendrometric variables of boles from trees qualified as neighbors, which suggests that arrangement between 
Table 6. Linear correlations of distance independent and semi-distance independent competition indexes for specimens classified in accordance to the ecologic groups.

\begin{tabular}{|c|c|c|c|c|c|c|c|c|}
\hline \multirow[b]{2}{*}{ Index } & \multicolumn{2}{|c|}{ Pioneer } & \multicolumn{2}{|c|}{ Early secondaries } & \multicolumn{2}{|c|}{ Late secondaries } & \multicolumn{2}{|c|}{ Climax } \\
\hline & $\triangle \mathrm{DBH}$ & $\Delta \mathbf{H t}$ & $\triangle \mathrm{DBH}$ & $\Delta \mathbf{H t}$ & $\triangle \mathrm{DBH}$ & $\Delta \mathbf{H t}$ & $\triangle \mathrm{DBH}$ & $\Delta \mathbf{H t}$ \\
\hline & & & & 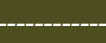 & & 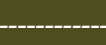 & ----- & \\
\hline IID1 & $1.99^{\mathrm{n} . \mathrm{s}}$ & $-1.60^{\mathrm{n} . \mathrm{s}}$ & $4.79^{*}$ & $0.12^{\mathrm{n} . \mathrm{s}}$ & $8.21^{\text {n.s }}$ & $7.47^{\mathrm{n} . \mathrm{s}}$ & $28.36^{*}$ & $3.40^{\text {n.s }}$ \\
\hline IID2 & $5.54^{\mathrm{n} . \mathrm{s}}$ & $-2.13^{\text {n.s }}$ & $7.75^{\star}$ & $-0.60^{\mathrm{n} . \mathrm{s}}$ & $15.07^{\mathrm{n} . \mathrm{s}}$ & $2.53^{\mathrm{n} . \mathrm{s}}$ & $23.39^{*}$ & $-2.95^{\mathrm{n} . \mathrm{s}}$ \\
\hline IID3 & $3.24^{\mathrm{n} . \mathrm{s}}$ & $-2.21^{\mathrm{n} . \mathrm{s}}$ & $6.98^{*}$ & $-1.14^{\mathrm{n} . \mathrm{s}}$ & $7.50^{\text {n.s }}$ & $2.29^{\mathrm{n} . \mathrm{s}}$ & $31.21^{*}$ & $4.46^{\text {n.s }}$ \\
\hline IID4 & $2.63^{\mathrm{n} . \mathrm{s}}$ & $0.43^{\mathrm{n} . \mathrm{s}}$ & $8.12^{*}$ & -1.07 & $5.06^{\text {n.s }}$ & $1.01^{\mathrm{n} . \mathrm{s}}$ & $29.49^{*}$ & $2.61^{\mathrm{n} . \mathrm{s}}$ \\
\hline IID5 & $-8.29^{*}$ & $6.45^{\mathrm{n} . \mathrm{s}}$ & $-9.50^{*}$ & $4.19^{\text {n.s }}$ & $-11.84^{*}$ & $1.20^{\mathrm{n} . \mathrm{s}}$ & $-24.31^{*}$ & $-5.32^{\mathrm{n} . \mathrm{s}}$ \\
\hline ISD1/ 2 & $-2.17^{\text {n.s }}$ & $0.88^{\mathrm{n} . \mathrm{s}}$ & $8.67^{\star}$ & $4.74^{*}$ & $7.07^{\text {n.s }}$ & $7.39^{\mathrm{n} . \mathrm{s}}$ & $22.45^{*}$ & $3.70^{\text {n.s }}$ \\
\hline ISD2/ 2 & $6.59^{\text {n.s }}$ & $0.34^{\mathrm{n} . \mathrm{s}}$ & $9.42^{\star}$ & $2.79^{\mathrm{n} . \mathrm{s}}$ & $8.39^{*}$ & $-1.42^{\mathrm{n} . \mathrm{s}}$ & $16.93^{*}$ & $3.01^{\text {n.s }}$ \\
\hline ISD3/ 2 & $-0.33^{\mathrm{n} . \mathrm{s}}$ & $1.24^{\mathrm{n} . \mathrm{s}}$ & $8.73^{*}$ & $4.11^{\mathrm{n} . \mathrm{s}}$ & $7.24^{\mathrm{n} . \mathrm{s}}$ & $3.34^{\mathrm{n} . \mathrm{s}}$ & $23.18^{\star}$ & $4.84^{\mathrm{n} . \mathrm{s}}$ \\
\hline ISD4/ 2 & $-3.07^{\mathrm{n} . \mathrm{s}}$ & $1.95^{\mathrm{n} . \mathrm{s}}$ & $10.36^{*}$ & $5.92^{*}$ & $5.97^{n . s}$ & $6.93^{\text {n.s }}$ & $20.36^{*}$ & $3.32^{n . s}$ \\
\hline ISD5/ 2 & $-2.99^{\mathrm{n} . s}$ & $5.40^{\mathrm{n} . \mathrm{s}}$ & $-1.22^{\mathrm{n} . \mathrm{s}}$ & $-5.20^{*}$ & $-3.10^{\mathrm{n} . \mathrm{s}}$ & $-1.47^{\mathrm{n} . \mathrm{s}}$ & $-13.40^{*}$ & $-1.06^{\mathrm{n} . \mathrm{s}}$ \\
\hline ISD1/ 3 & $-1.15^{\mathrm{n} . \mathrm{s}}$ & $-2.14^{\mathrm{n} . s}$ & $7.70^{*}$ & $4.11^{\mathrm{n} . \mathrm{s}}$ & $10.00^{*}$ & $7.59^{\text {n.s }}$ & $24.66^{\star}$ & $1.26^{\mathrm{n} . \mathrm{s}}$ \\
\hline ISD2/ 3 & $6.48^{\mathrm{n} . \mathrm{s}}$ & $-3.36^{\text {n.s }}$ & $8.04^{*}$ & $1.23^{\mathrm{n} . \mathrm{s}}$ & $14.58^{*}$ & $0.63^{\text {n.s }}$ & $21.10^{*}$ & $-0.06^{\mathrm{n} . \mathrm{s}}$ \\
\hline ISD3/ 3 & $0.94^{\mathrm{n} . \mathrm{s}}$ & $-2.13^{n . s}$ & $8.45^{\star}$ & $3.91^{\text {n.s }}$ & $10.44^{\star}$ & $3.60^{\text {n.s }}$ & $26.49^{*}$ & $2.38 \mathrm{v}$ \\
\hline ISD4/ 3 & $-1.91^{\mathrm{n} . \mathrm{s}}$ & $-1.16^{\mathrm{n} . \mathrm{s}}$ & $8.85^{\star}$ & $5.60^{*}$ & $9.63^{*}$ & $6.81^{\mathrm{n} . \mathrm{s}}$ & $23.72^{\star}$ & $1.54^{\mathrm{n} . \mathrm{s}}$ \\
\hline ISD5/ 3 & $-2.64^{\mathrm{n} . \mathrm{s}}$ & $5.40^{\text {n.s }}$ & $-2.34^{\mathrm{n} . \mathrm{s}}$ & $-2.48^{\mathrm{n} . \mathrm{s}}$ & $-6.28^{\mathrm{n} . \mathrm{s}}$ & $-1.54^{\mathrm{n} . \mathrm{s}}$ & $-5.40^{\mathrm{n} . \mathrm{s}}$ & $4.42^{\mathrm{n} . \mathrm{s}}$ \\
\hline ISD1/ 4 & $-1.90^{\text {n.s }}$ & $0.53^{\text {n.s }}$ & $3.24^{\mathrm{n} . \mathrm{s}}$ & $3.26^{\text {n.s }}$ & $11.46^{\star}$ & $9.06^{\text {n.s }}$ & $21.67^{\star}$ & $1.92^{\text {n.s }}$ \\
\hline ISD2/ 4 & $5.86^{\text {n.s }}$ & $-0.79^{\mathrm{n} . \mathrm{s}}$ & $7.75^{\star}$ & $1.56^{\text {n.s }}$ & $16.49^{\star}$ & $2.89^{\mathrm{n} . \mathrm{s}}$ & $19.28^{*}$ & $-0.73^{\mathrm{n} . \mathrm{s}}$ \\
\hline ISD3/ 4 & $0.25^{\mathrm{n} . \mathrm{s}}$ & $0.82^{\text {n.s }}$ & $4.41^{\mathrm{n} . \mathrm{s}}$ & $2.93^{n . s}$ & $12.45^{\star}$ & $4.12^{\mathrm{n} . \mathrm{s}}$ & $22.90^{*}$ & $2.14^{\mathrm{n} . \mathrm{s}}$ \\
\hline ISD4/ 4 & $-2.33^{n . s}$ & $1.54^{\text {n.s }}$ & $6.46^{\star}$ & $3.71^{\text {n.s }}$ & $11.46^{\star}$ & $7.22^{\text {n.s }}$ & $20.47^{\star}$ & $1.86^{\mathrm{n} . \mathrm{s}}$ \\
\hline ISD5/ 4 & $-4.29^{\text {n.s }}$ & $0.21^{\mathrm{n} . \mathrm{s}}$ & $-3.20^{\text {n.s }}$ & $-2.06^{\text {n.s }}$ & $-8.25^{\star}$ & $-4.94^{\mathrm{n} . \mathrm{s}}$ & $-8.78^{\mathrm{n} . \mathrm{s}}$ & $-0.19^{\mathrm{n} . \mathrm{s}}$ \\
\hline ISD1/ 5 & $-0.60^{\mathrm{n} . \mathrm{s}}$ & $-0.43^{n . s}$ & $4.56^{\mathrm{n} . \mathrm{s}}$ & $3.93^{n . s}$ & $10.29^{\star}$ & $8.20^{\text {n.s }}$ & $24.73^{*}$ & $2.13^{n . s}$ \\
\hline ISD2/ 5 & $7.45^{\mathrm{n} . \mathrm{s}}$ & $-0.36^{\mathrm{n} . \mathrm{s}}$ & $7.20^{*}$ & $1.97^{\text {n.s }}$ & $15.69^{*}$ & $1.66^{\mathrm{n} . \mathrm{s}}$ & $18.94^{*}$ & $-1.60^{\mathrm{n} . \mathrm{s}}$ \\
\hline ISD3 /5 & $1.07^{\text {n.s }}$ & $-0.40^{\mathrm{n} . \mathrm{s}}$ & $5.62^{\star}$ & $3.21^{\mathrm{n} . \mathrm{s}}$ & $10.26^{\star}$ & $2.94^{\mathrm{n} . \mathrm{s}}$ & $26.33^{*}$ & $2.55^{\text {n.s }}$ \\
\hline ISD4/ 5 & $-1.08^{\text {n.s }}$ & $0.04^{\text {n.s }}$ & $7.39^{*}$ & $4.11^{\mathrm{n} . \mathrm{s}}$ & $9.71^{*}$ & $5.83^{\text {n.s }}$ & $25.33^{*}$ & $2.47^{\text {n.s }}$ \\
\hline ISD5/ 5 & $-8.50^{*}$ & $0.19^{\mathrm{n} . \mathrm{s}}$ & $-3.83^{\mathrm{n} . \mathrm{s}}$ & $-1.34^{\mathrm{n} . \mathrm{s}}$ & $-8.37^{\star}$ & $-4.50^{\mathrm{n} . \mathrm{s}}$ & $-12.27^{\star}$ & $-3.43^{\mathrm{n} . \mathrm{s}}$ \\
\hline ISD1/ 6 & $0.32^{n . s}$ & $0.33^{\text {n.s }}$ & $1.83^{\mathrm{n} . \mathrm{s}}$ & $3.25^{\text {n.s }}$ & $11.15^{\star}$ & $9.94^{\mathrm{n} . \mathrm{s}}$ & $23.51^{*}$ & $2.38^{\text {n.s }}$ \\
\hline ISD2/ 6 & $9.01^{*}$ & $-0.17^{\mathrm{n} . \mathrm{s}}$ & $6.50^{*}$ & $0.75^{n . s}$ & $16.75^{*}$ & $2.51^{\mathrm{n} . \mathrm{s}}$ & $20.04^{*}$ & $-1.58^{\mathrm{n} . \mathrm{s}}$ \\
\hline ISD3/ 6 & $2.28^{\text {n.s }}$ & $0.37^{\mathrm{n} . \mathrm{s}}$ & $2.46^{\mathrm{n} . s}$ & $2.46^{\text {n.s }}$ & $11.29^{*}$ & $4.12^{\mathrm{n} . \mathrm{s}}$ & $24.75^{*}$ & $3.11^{\mathrm{n} . \mathrm{s}}$ \\
\hline ISD4/ 6 & $0.13^{\text {n.s }}$ & $1.27^{\mathrm{n} . \mathrm{s}}$ & $3.56^{\mathrm{n} . \mathrm{s}}$ & $3.67^{\text {n.s }}$ & $9.49^{\star}$ & $7.40^{\text {n.s }}$ & $23.63^{\star}$ & $2.11^{\mathrm{n} . \mathrm{s}}$ \\
\hline ISD5/ 6 & $-8.40^{*}$ & $0.50^{\mathrm{n} . \mathrm{s}}$ & $-4.87^{\star}$ & $-1.11^{\mathrm{n} . \mathrm{s}}$ & $-7.38^{\text {n.s }}$ & $-4.93^{\mathrm{n} . \mathrm{s}}$ & $-14.18^{*}$ & $0.46^{\text {n.s }}$ \\
\hline
\end{tabular}

*: indicate meaningful correlations; n.s.: indicate non-meaningful correlations, by $95 \%$ of probability; $\Delta \mathrm{DBH}$ : growth in diameter; $\Delta \mathrm{Ht}$ : growth in height.

dendrometric variables can bring results that better represent competition.

With the results obtained within this research, one may observe the superiority on the values of correlations between BAL index, without influence of radius, within the climax group, in relation to the work of Castro et al. (2014). These authors have found a correlation of $20 \%$, while this work has presented a correlation of $24.31 \%$ regarding diametrical growth. Yet, for the correlation between indexes and growth in height, the authors have found $12 \%$ as the greatest meaningful correlation, while for this study no meaningful correlations were obtained.

It is worth mentioning that data applied within this work are characterized as having the same kind of 
vegetation from the studies cited above, which allows a greater consistency in the contrast between both researches. Height variable behavior can be justified by the level of difficulty in obtaining it or even by its relation to growth in a natural environment, given the multiplicity of factors that influence its dynamics.

Analysis of climax successional group has shown that distance independent indexes, as well as semi-distance dependent with radius of 2, 5, and 6 meters of distance, were adequate to competition evaluation. When observing classification of individuals in groups regarding their need for light, light demanding and shade tolerant, it is possible to notice that the correlations were inferior to those found when individuals were organized according to successional group (Table 7).

Table 7. Linear correlations between the distance independent and semi-distance dependent competition indexes for all specimens classified according to light demanding.

\begin{tabular}{|c|c|c|c|c|}
\hline \multirow{3}{*}{ Index } & \multicolumn{2}{|c|}{ Light demanding } & \multicolumn{2}{|c|}{ Shade tolerant } \\
\hline & $\triangle \mathrm{DBH}$ & $\Delta \mathrm{Ht}$ & $\triangle \mathrm{DBH}$ & $\Delta \mathrm{Ht}$ \\
\hline & & --- & $\%$ & \\
\hline IID1 & $5.19^{\star}$ & $-0.03^{\text {n.s }}$ & $5.79^{*}$ & $1.41^{\mathrm{n} . \mathrm{s}}$ \\
\hline IID2 & $7.17^{*}$ & $-1.52^{\mathrm{n} . \mathrm{s}}$ & $9.39^{*}$ & $0.05^{\text {n.s }}$ \\
\hline IID3 & $7.30^{\star}$ & $-0.92^{\mathrm{n} . \mathrm{s}}$ & $7.49^{*}$ & $-0.45^{\mathrm{n} . \mathrm{s}}$ \\
\hline IID4 & $8.11^{*}$ & $-0.75^{\mathrm{n} . \mathrm{s}}$ & $8.01^{*}$ & $-0.81^{\mathrm{n} . \mathrm{s}}$ \\
\hline IID5 & $-9.42^{\star}$ & $4.23^{*}$ & $-10.42^{*}$ & $2.73^{\text {n.s }}$ \\
\hline ISD1/ 2 & $7.44^{*}$ & $3.51^{\text {n.s }}$ & $8.83^{*}$ & $5.26^{*}$ \\
\hline ISD2/ 2 & $8.48^{\star}$ & $1.89^{\mathrm{n} . \mathrm{s}}$ & $9.37^{\star}$ & $1.79^{\text {n.s }}$ \\
\hline ISD3/ 2 & $7.98^{\star}$ & $3.35^{\text {n.s }}$ & $8.93^{*}$ & $3.92^{*}$ \\
\hline ISD4/ 2 & $8.43^{\star}$ & $4.51^{\star}$ & $9.73^{*}$ & $5.93^{*}$ \\
\hline ISD5/ 2 & $-1.24^{\mathrm{n} . \mathrm{s}}$ & $-2.85^{n . s}$ & $-1.75^{\mathrm{n} . \mathrm{s}}$ & $-4.20^{*}$ \\
\hline ISD1/ 3 & $6.96^{*}$ & $2.34^{\mathrm{n} . s}$ & $8.63^{*}$ & $4.70^{*}$ \\
\hline ISD2/ 3 & $7.48^{*}$ & $-0.33^{\text {n.s }}$ & $9.50^{*}$ & $1.00^{\text {n.s }}$ \\
\hline ISD3/ 3 & $8.11^{*}$ & $2.48^{\mathrm{n} . \mathrm{s}}$ & $9.28^{*}$ & $3.69^{\text {n.s }}$ \\
\hline ISD4/ 3 & $7.91^{*}$ & $3.75^{\mathrm{n} . \mathrm{s}}$ & $9.31^{*}$ & $5.58^{*}$ \\
\hline ISD5/ 3 & $-1.72^{\mathrm{n} . \mathrm{s}}$ & $-0.34^{\text {n.s }}$ & $-2.83^{\mathrm{n} . \mathrm{s}}$ & $-1.83^{\mathrm{n} . \mathrm{s}}$ \\
\hline ISD1/ 4 & $3.25^{\mathrm{n} . \mathrm{s}}$ & $2.47^{\text {n.s }}$ & $5.20^{*}$ & $4.47^{\star}$ \\
\hline ISD2/ 4 & $7.16^{*}$ & $0.55^{\text {n.s }}$ & $9.49^{*}$ & $1.75^{\mathrm{n} . \mathrm{s}}$ \\
\hline ISD3/ 4 & $4.65^{*}$ & $2.40^{\text {n.s }}$ & $6.29^{*}$ & $3.13^{\text {n.s }}$ \\
\hline ISD4/ 4 & $6.13^{*}$ & $3.07^{\text {n.s }}$ & $7.61^{\star}$ & $4.33^{*}$ \\
\hline ISD5/ 4 & $-2.78^{\mathrm{n} . \mathrm{s}}$ & $-1.13^{n . s}$ & $-4.21^{\star}$ & $-2.68^{n . s}$ \\
\hline ISD1/ 5 & $4.60^{\star}$ & $2.81^{\mathrm{n} . \mathrm{s}}$ & $6.04^{\star}$ & $4.55^{\star}$ \\
\hline ISD2/ 5 & $6.95^{\star}$ & $0.79^{\text {n.s }}$ & $8.96^{*}$ & $1.61^{\mathrm{n} . \mathrm{s}}$ \\
\hline ISD3 /5 & $5.82^{\star}$ & $2.44^{\mathrm{n} . \mathrm{s}}$ & $6.84^{*}$ & $2.98^{\mathrm{n} . s}$ \\
\hline ISD4/ 5 & $7.24^{\star}$ & $3.22^{\mathrm{n} . \mathrm{s}}$ & $8.12^{*}$ & $4.11^{*}$ \\
\hline ISD5/ 5 & $-4.23^{\star}$ & $-0.94^{\text {n.s }}$ & $-4.99^{\star}$ & $-2.33^{\text {n.s }}$ \\
\hline ISD1/ 6 & $2.19^{\text {n.s }}$ & $2.39^{\text {n.s }}$ & $3.84^{\star}$ & $4.43^{*}$ \\
\hline ISD2/ 6 & $6.60^{*}$ & $-0.04^{\mathrm{n} . \mathrm{s}}$ & $8.70^{*}$ & $1.00^{\mathrm{n} . \mathrm{s}}$ \\
\hline ISD3/ 6 & $2.98^{\mathrm{n} . \mathrm{s}}$ & $1.94^{\mathrm{n} . \mathrm{s}}$ & $4.27^{\star}$ & $2.69^{n . s}$ \\
\hline ISD4/ 6 & $3.75^{\text {n.s }}$ & $2.99^{\text {n.s }}$ & $4.68^{\star}$ & $3.99^{*}$ \\
\hline ISD5/ 6 & $-5.11^{\star}$ & $-0.21^{\mathrm{n} . \mathrm{s}}$ & $-5.80^{*}$ & $-1.94^{\text {n.s }}$ \\
\hline
\end{tabular}

*: indicate meaningful correlations; $n$.s.: indicate non-meaningful correlations, by $95 \%$ of probability; $\Delta \mathrm{DBH}$ : growth in diameter; $\Delta \mathrm{Ht}$ : growth in height. 
According to Carvalho (1997), the main factor that determines species behavior is solar radiation. Therefore, it was pertinent to evaluate forest competition by groups defined as tolerant and intolerant to shade, demanding for light, and shade tolerant, respectively. The greatest correlations between diametrical growth and competition indexes presented by light demanding and shade tolerant groups were, respectively, $9.42 \%$ and $10.42 \%$. Both were obtained by applying BAL index (IID5) in a distance independent way. Some authors recommend including within modeling competition indexes that do not consider space. However, for the shade tolerant group, semi-distance dependent indexes with radius of 5,6 , and 7 meters have presented meaningful correlations, and in some bigger cases, independent on the adopted index.

By analyzing the competition by groups according to light demand, it has been verified that competition influences the growth in height of both groups. The light demanding group has had only two meaningful correlations, the greater one being obtained through ISD4/2. As for the shade tolerant group, this very same index has presented the greatest correlation among the rest. According to Vaccaro et al. (2003), non-shade tolerant species grow faster than those from other ecologic groups. When one studies the behavior of these groups in relation to dimension, the aforementioned authors point out that usually tall trees grow faster in diameter, both in old-growth forest as in logged ones, due to tall trees having higher possibilities of their crowns to be completely exposed to sunlight, and because they have bigger crowns, they present a higher liquid production.

It is important to mention that BAL index, distance independent and semi-distance dependent, has not presented satisfactory results for the variable $\mathrm{Ht}$ in the evaluation of competition by groups classified according to their demand for light. Therefore, it is not recommended to apply that index to evaluate forest competition according to growth in height. Such behavior can be explained by its functional formula, which considers the basal area of neighboring individuals.

Nevertheless, according to Chassot et al. (2011), there is no confirmation of universal superiority regarding one kind of index over another, nor about which would be the best index within each category, even less as for applying each index category to successional groups.

\section{CONCLUSIONS}

i) The insertion of height variable has not showed efficiency on applying competition indexes.

ii) In natural forests, evaluation of competition made by ecologic groups has proved to be a satisfactory alternative to solve difficulty provided by high diversity of these environments.

iii) Forest competition can be determined by applying a fixed radius of influence of neighbors in relation to the subject tree, since BAL index has presented meaningful correlations; yet it has not invalidated the application of other indexes.

iv) BAL index, with no radius of influence, has achieved the best performance to analyze the competition's influence on individuals' growth within the studied fragment.

\section{ACKNOWLEDGEMENTS}

Coordenação de Aperfeiçoamento de Pessoal de Nível Superior (Capes).

\section{SUBMISSION STATUS}

Received: 9 Mar., 2016

Accepted: 10 July, 2018

\section{CORRESPONDENCE TO}

\section{Ilvan Medeiros Lustosa Junior}

Universidade de Brasília (UnB), Asa Norte, CEP 70910-900, Brasília, DF, Brasil

e-mail: ilvan.junior@ifb.edu.br

\section{REFERENCES}

Béland M, Lussier JM, Bergeron Y, Longpré MH. Structure, spatial distribution and competition in mixed jack pine (Pinus banksiana ) stands on clay soils of eastern Canadá. Annals of Forest Science 2003; 60(7): 609-617. 10.1051/ forest:2003053

Biging GS, Dobbertin M. Evaluation of competition indices in individual tree growth models. Forest Science 1995; 41(2): 360-377. 10.1093/forestscience/41.2.360

Boivin F, Paquette A, Papaik MJ, Thiffault N, Messier C. Do position and species identity of neighbours matter in 8-15-year-old post harvest mesic stands in the boreal 
mixedwood? Forest Ecology and Management 2010;260(7): 1124-1131. 10.1016/j.foreco.2010.06.037

Carvalho JOP. Dinâmica de florestas naturais e sua implicação para o manejo florestal. In: Curso de Manejo Florestal Sustentável; 1997; Curitiba. Colombo: EmbrapaCNPF; 1997. p. 43-55.

Castro RVO, Soares CPB, Leite HG, Souza AL, Martins FB, Nogueira GS et al. Competição em nível de árvore individual de uma floresta estacional semidecidual. Silva Lusitana 2014; 22(1): 43-66.

Chassot T, Fleig FD, Finger CAG, Longhi SJ. Modelos de crescimento em diâmetro de árvores individuais de Araucária angustifólia (Bertol.) Kuntze em floresta ombrófila mista. Ciência Florestal 2011; 21(2): 303-313. $10.5902 / 198050983234$

Contreras MA, Affleck D, Chung W. Evaluating tree competition indices as predictors of basal area increment in western Montana forests. Forest Ecology and Management 2011; 262(11): 1939-1949. 10.1016/j. foreco.2011.08.031

Cunha TA. Modelagem do incremento de árvores individuais de Cedrela odorata L. na Floresta Amazônica [dissertação]. Santa Maria: Universidade Federal de Santa Maria; 2009.

Cunha TA, Finger CAG. Competição assimétrica e o incremento diamétrico de árvores individuais de Cedrela odorata L. na Amazônia ocidental. Acta Amazônica 2013; 43(1): 9-18. 10.1590/S0044-59672013000100002

Das A. The effect of size and competition on tree growth rate in old-growth coniferous forests. Canadian Journal of Forest Research 2012; 42(11): 1983-1995. 10.1139/ x2012-142

Eid T, Tuhus E. Models for individual tree mortality in Norway. Forest Ecology and Management 2001; 154(1-2): 175-184. 10.1016/S0378-1127(00)00634-4

Gaspar RO, Castro RV, Peloso RVD, Souza FC, Martins SV. Análise fitossociológica e do estoque de carbono no estrato arbóreo de um fragmento de floresta estacional semidecidual. Ciência Florestal 2014; 24(2): 313-324. 10.5902/1980509814569

Glover GR, Hool JN. A basal area ratio predictor of loblolly pine plantation mortality. Forest Science 1979; 25(2): 275282. $10.1093 /$ forestscience/25.2.275
Hynynen J. Predicting tree crown ratio for unthinned and thinned Scots pine stands. Canadian Journal of Forest Research 1995; 25(1): 57-62. 10.1139/x95-007

Instituto Brasileiro de Geografia e Estatística - IBGE. Manual técnico da vegetação brasileira. 2 nd ed. Rio de Janeiro; 2012 [cited 2017 Nov 5]. Available from: https:// bit.ly/2Cz2phD

Lee Y. Predicting mortality for even-aged stands of lodgepole pine. Forestry Chronicle 1971; 47(1): 29-32.

Lorimer CG. Tests of age-independent competition indices for individual trees in natural hardwood stands. Forest Ecology and Management 1983; 6(4): 343-360. 10.1016/0378-1127(83)90042-7

Martins FB, Soares CPB, Leite HG, Souza AL, Castro RVO. Índices de competição em árvores individuais de eucalipto. Pesquisa Agropecuária Brasileira 2011; 46(9): 1089-1098. 10.1590/S0100-204X2011000900017

Orellana E, Figueiredo Filho A, Péllico Netto S, Vanclay JK. A distance-independent individual-tree growth model to simulate management regimes in native Araucaria forests. Journal of Forest Research 2016; 22(1): 30-35. 10.1080/13416979.2016.1258961

Silva JNM, Carvalho JOP, Lopes JCA, Almeida BF, Costa DHM, Oliveira LC et al. Growth and yield of a tropical rain forest in the Brazilian Amazon after 13 years after logging. Forest Ecology and Management 1995; 71(3): 267-274. 10.1016/0378-1127(94)06106-S

Stage AR. Prognosis models for stand development. Ogden: USDA Forest Service; 1973.

Stage AR, Ledermann T. Effects of competitor spacing in a new class of individual-tree indices of competition: semidistance-independent indices computed for Bitterlich versus fixed-area plots. Canadian Journal of Forest Research 2008; 38(4): 890-898. 10.1139/X07-192

Vaccaro S, Finger CAG, Schneider PR, Longhi SJ. Incremento em área basal de árvores de uma floresta estacional decidual, em três fases sucessionais, no município de Santa Tereza, RS. Ciência Florestal 2003; 13(2): 131-142. 10.5902/198050981749

Weber P, Bugmann H, Fonti P, Rigling A. Using a retrospective dynamic competition index to reconstruct forest succession. Forest Ecology and Management 2008; 254: 96-106. 10.1016/j.foreco.2007.07.031 